\title{
The Practice of Chuquan by Queer NGOs in China
}

\author{
Yuqi Guo ${ }^{1, *}$
}

\author{
${ }^{I}$ The University of Edinburgh, UK \\ *Corresponding author. Email: guoyq77@foxmail.com
}

\begin{abstract}
This article examines how queer NGOs in China gain visibility, chuquan (出圈) in Chinese, for the NGOs themselves and the queer community in legal and public spheres. It argues that the reasons why they gain political and social visibility are to acquire political and economic legitimacy, and social and cultural awareness among the public. It also analyzes how the NGOs try to solve the various challenges they face. Through legitimacy and public awareness, the NGOs could gain visibility to produce a positive image of the queer community and increase the acceptability of queer NGOs and queer people in China.
\end{abstract}

Keywords: Queer, NGOs, Visibility, China

\section{INTRODUCTION}

With rapid social and economic changes in China in the post-Mao era, individual desires are open to more discussion and the topic of gender, especially queer, has been circulated more than before. However, there are still restrictions of political forces and social norms that limit sexual and gender minorities. This article examines the restrictions that these minorities face and how gender NGOs created for them deal with the challenges. The main argument in this article is that queer NGOs in China gain political and social visibility through acquiring legitimacy and public awareness among the society. Queer activists in China negotiate the space of visibility, adjust what can be visible and what has to be invisible in their everyday practice. This article begins with a literature review of queer visibility in China to illustrate how Chinese queer activists engage with visibility. The next two sections move on to discuss why the queer NGOs need to gain visibility - to acquire legitimacy and to promote public awareness.

The methodology of this research is ethnography with a main method of participant observation. The fieldwork was conducted mainly in March and April in 2021. Joining the NGOs as a volunteer, I worked with them, joined several LGBT community group chats created by the NGOs on social media and participated some public activities organized by them.

\section{VISIBILITY AS LEGITIMACY ACQUISITION AND PUBLIC AWARENESS}

Seeking visibility is a critical issue for queer NGOs in China. It is understood and analyzed as NGOs' efforts to gain legitimacy and public awareness in a specific social context.

In China, due to political situations, queer activists could not have public confrontation with the government, so they strategically cooperate with the state to negotiate social visibility and attain legitimacy and public awareness. Some scholars focus on the legitimate existence of HIV NGOs, to discuss how queer activists grasp the political opportunity out of public health issues to gain the legitimacy of HIV NGOs [1]. Other scholars report queer NGOs' legitimate cooperation with official organizations to strategically find the common ground that could be shared with them [2]. In addition, some scholars report that Chinese queer activists and NGOs also take advantage of the legitimacy of consumerism by making use of the development of pink economy and hold queer commercial activities for entertainment to increase visibility [3]. With respect to public consciousness, some queer organizations raise social awareness of queer issues in China through media [4], while others justify queer people as homonormative, and highlight queer people's positive images [5]. In this way, queer activists and NGOs make efforts to cultivate queer 
people's image of friendliness and normativity against the backdrop of Chinese society.

In this context, Chinese queer NGOs take the bottom-up strategy of visibility to make social changes through everyday practice in relation between the minority and the majority, and they establish an unconfrontational and dynamic relationship with power by means of reciprocity, similarity, and cooperation with a goal of recognition. Taking the initiative of being the object of visibility, they want to be seen and be recognized by the society through politico-economic legitimacy and socio-cultural consciousness. Therefore, this article reveals the specific ways the queer NGOs use to boost visibility, chuquan (出圈) in Chinese, in legal and public spheres and analyzes how the NGOs try to solve various challenges they face.

\section{GAINING LEGITIMACY}

The ways to gain visibility by queer NGOs in China is often called chuquan by them. Chuquan (出圈), a verb or a noun in Chinese, means that a person, an event, or an object, initially popular in a relatively small field or circle, becomes popular and known by people outside it. The literal translation of chuquan is to go outside of the circle and expand the circle of influence to people outside. In this article, chuquan means that LGBT NGOs try to expand the influence of both the NGOs themselves and the topic of LGBT, which are mainly well-known within the LGBT circle, in order for them to reach the people not belonging to the LGBT community. Since the topic of LGBT is still a sensitive issue in China, in order to protect the safety and the privacy of the staff in queer NGOs and the members of the LGBT community, the names and the locations that might disclose any information or feature of the NGOs will not be revealed, and several LGBT NGOs will be discussed as a whole instead of each NGO separately.

The first reason why the NGOs want to chuquan is to gain legitimacy of both the NGOs and the queer topic that they try to circulate. Due to current political situations in China, the staff in the queer centers know well that it is hard to gain the acknowledgement and support from the government, so they do not expect to gain much legitimacy of the NGOs from the government; instead, what they most want to gain is the legitimacy of the LGBT topic for the time being. Therefore, their desire of chuquan is more likely to be realized by them focusing on the legitimate topic to go viral outside of the LGBT community and be spread widely in the society, which could have sufficient influence among the society and hopefully make the NGOs become acknowledged by the government in the future. This section first discusses the challenges the NGOs face, and then how the NGOs chuquan with the government to gain legitimacy. Finally, it describes how the NGOs chuquan to enterprises.
The political environment is challenging for the NGOs, since the government's attitude towards LGBT is neither supporting nor opposing. In general, there are many acquiescent limitations on the queer topic. For example, the word LGBT does not exist in the law. Thus, the wives of gay men could not safeguard their rights, because if gay men's extramarital affairs are recognized by the law, it means that the government accept the love between homosexual people. Also, books about the LGBT topic cannot be legally published. Keywords about LGBT are filtered on media platforms. People working in the political system cannot come out publicly for fear of being fired. Students and professors in universities could not do research on LGBT issues.

Despite all these challenges, the NGOs still practice chuquan to gain legitimacy in the space permitted. They gain legitimacy of themselves and the queer topic by finding shared interests with the government. The first way is to build relationship with individual officials working in the government to gain legitimate support and chuquan. They could also contact the government through legitimate official channel, such as the channel of correspondence and complaint (xinfang), where they could ask questions by writing letters to National Health Commission of the People's Republic of China. The third way for the NGOs to gain legitimacy and chuquan is to find shared interest with the government, such as the public health issue of HIV, which is a problem attended to by both the government and the NGOs. In addition, the NGOs take advantage of the government's official statement supporting LGBT rights to spread the message of the legitimacy of queer topic to the society. This is because although the government does not actually do things to protect or care about the LGBT community, it has to make a claim to the globe when needed.

The NGOs not only gain legitimacy and chuquan with the government, but also to enterprises. They make friends with individuals working in companies and collaborate with companies to make them aware that the queer issues also exist in the workplace. One thing they did was that they translated into Chinese an English report about the relationship between companies' attitudes towards LGBT issues and their performance to let the companies know the legitimacy of the queer topic and make the companies more open to LGBT people. To circulate this report, the NGOs held a report launch event. They invited people working in human resources department and public relations department in different foreign companies, private enterprises, and state-owned enterprises to attend the event. However, most of the people who actually turned up were from international companies, with only a few people from private enterprises and no people from state-owned enterprises. 
During the launch event, the NGOs not only introduced this report, but also shared some moving and positive LGBT-friendly stories to the audience. One staff member said,

One true story that really touched me was that one day a father working in an international company came home with a little rainbow flag. He sent this flag to his daughter and said, 'dear if you are a member of this community when you grow up, I will support you forever.

The NGOs invited some attendees working in international companies to share what their own companies had done to support the queer community so that other companies could follow the examples and increase the influence of this topic. They also welcomed everyone to become a member of the LGBT community, because one letter ' $\mathrm{A}$ ' in the string 'LGBTQQIAA+' refers to 'ally'. Hence, 'if you support the LGBT issue, you are also a member of this family and we welcome all of you,' said a staff member.

In the launch event, what the NGOs spread to the companies was full of positive stories, ideal dreams and hope with frequently occurred words such as 'we hope we will...... in the future'. After the launch event, I asked a person who worked in an international company why companies would like to support the LGBT community if the government did not have a positive attitude. He said, 'it is much safer for companies to publicly support the LGBT community than publicly release anti-discrimination statement.' The NGOs find a safe and flexible space for the companies where the companies would not only avoid running in the risk of being punished by the government, but also find a way to increase their revenue by supporting the queer community. In this way, the NGOs find a common interest shared by companies and themselves through persuading the attendees that according to the research, companies who have a public statement of supporting the LGBT community could have a higher proportion of international revenue, can attract, and retain more talented employees. This is their way of gaining the legitimacy of the queer topic.

Therefore, having learned their relationship with the government clearly, the staff in the queer NGOs know what they can do in the present - fighting for the legitimacy of themselves and more importantly the queer topic by sharing different interests with different stakeholders. They spread the information and concept upwards to the government and horizontally to their counterparts, such as companies. However, the topdown changes are hard for now, but the bottom-up alterations can be achieved. Therefore, the next section discusses how the NGOs spread the queer topic downwards to citizens in the society.

\section{INCREASING AWARENESS}

In addition to gaining legitimacy of the queer topic, another reason why the NGOs practice chuquan is to increase people's awareness of the queer topic. By the NGOs raising public awareness, people outside the circle of LGBT would learn more about the queer community. This section first analyzes challenges the NGOs face. It then illustrates how they increase the awareness of people beyond the circle, such as lawyers, doctors, and psychological counselors.

The NGOs face many challenges when they tried to raise public awareness of the queer issue. One staff member thought that due to the censorship in China it was hard to discuss the queer issue openly. As a result, most people do not know what the word LGBT refers to, which is similar to the fact that most people in China still think feminism is an irrational movement that women fight against men in order to acquire a higher position than men have. In the center of the LGBT circle, there are people who work actively and who have knowledge on the issue; on the periphery of the circle there are people interested in gender issues; outside of this circle, few people are familiar with the topic. What is worse, there is nearly no communication between the people inside the circle and the people outside. As a transgender girl once said, 'I don't quite often talk to cisgender heterosexual people, because we are like living in two different worlds.' Under the pressure both inside and outside the circle, the NGOs encounter a myriad of difficulties when practicing chuquan.

In spite of the countless challenges they face, the NGOs have done many things to raise public awareness of the normality of queer people's everyday life. They collaborate with lawyers outside the circle to help members safeguard their rights, such as helping transgender people modify genders on their academic certificates. They also collaborate with doctors outside the circle to provide physical and mental support and information. Facing various pressures, many LGBT people encounter mental problems, so the NGOs also collaborate with psychological counselors outside the circle to give emotional and mental support.

The NGOs create LGBT-friendly training programs for psychological counselors every year to make them aware that the LGBT issues are closely related to their work, so that they could be LGBT-friendly in their counseling services. They also welcome other people who are interested in the topic, which could enlarge the potential circle of influence. At the beginning of the course, the staff members in the NGOs introduced what the NGOs had achieved in the field of psychological counseling, how they collaborated with different institutions doing research on psychology, and the fact that how many psychological counselors were in the NGOs. In doing so, they expected to win the trust of the 
participants in the course, which could make their gender education more easily. During the session, a staff member introduced the concept of LGBT by talking about something people are familiar with in their daily lives, and gradually guided people into the correct way of looking at LGBT people and explained the normality of the LGBT people, to raise participants' awareness of the current gender issues.

After the course, the staff members gave students an assignment to post what they had learned in the course on social media. Given the fact that most psychological counselors were cisgender heterosexual people, one person said once he had posted an article about LGBT people, his relatives doubted he was homosexual and told it to his parents. After hearing this story, another person hesitated to post his own thoughts on social media for fear of people's misunderstanding of his motivation. During their discussion, one psychological counselor said,

So, it is an interesting experience. You may never have had this kind of concern before, but when you are asked to complete this assignment, you experience the concern and pressure that only LGBT people would have. In this way, you can empathize with your LGBT consultants in the future.

By leading people from their familiar topic to the topic that are a little strange for them and making them immersed in the experience that LGBT people may have in their lives, the NGOs successfully deliver gender education to the psychological counselors who begin to think and learn about the normality of the LGBT community.

\section{CONCLUSION}

This article reveals how the queer NGOs chuquan in politico-economic and socio-cultural spheres and how they deal with the challenges they face when gaining LGBT visibility. The NGOs communicate with people in different social fields through their daily operation, public activities, and semi-formal cooperation to spread the information of the NGOs themselves and the queer topic. It shows that through legitimacy and public awareness, they could gain visibility to produce a positive image of the queer community and increase the acceptability of the queer NGOs and queer people.

The Chinese case in this article resonates with the issues discussed in queer studies, which are political inclusion and recognition, and social acceptability of difference [6]. This research provides a contextual analysis of how Chinese queers and the NGOs have strived for the goals through the discourse and practice of chuquan. It also offers an insight on queer visibility and its social acceptability in China, which has not been fully discussed before. Future studies could delve deeply into how queer NGOs gain visibility in different fields in China.

\section{ACKNOWLEDGMENTS}

The author would like to thank professor Qiaoyun Zhang for her valuable guidance and concrete suggestions throughout the whole writing process. I extend my appreciation and gratitude to the dedicated Chinese queer NGO members who participated in this research.

\section{REFERENCES}

[1] C. J. Miller, We Can Only Be Healthy if We Love Ourselves: Queer AIDS NGOs, Kinship, and Alternative Families of Care in China, AIDS Care 28(54) (2016) 51-60. DOI: https://doi.org/10.1080/09540121.2016.1195481

[2] L. Rofel, Grassroots activism: Non-normative sexual politics in post-socialist China, in: W. Sun, Y. Guo (Eds.), Unequal China: The Political Economy and Cultural Politics of Inequality, Routledge, London, New York, 2012, pp. 154-167.

[3] X. He, Chinese queer (tongzhi) women organizing in the 1990s, in: P.-C. Hsiung, M. Jaschok, C. Milwertz, R. Chan (Eds.), Chinese Women Organizing: Cadres, Feminists, Muslims, Queers, Bloomsbury Academic, London, 2001, pp. 41-59.

[4] X. Wei, S. Deklerck, Queer online media and the building of China's LGBT community, in: E. L. Engebretsen, W. F. Schroeder, H. Bao (Eds.), Queer/Tongzhi China: New Perspectives on Research, Activism and Media Cultures, NIAS Press, Copenhagen, 2015, pp. 18-34.

[5] H. Bao, Queer Comrades: Gay Identity and Tongzhi Activism in Postsocialist China, NIAS Press, 2018.

[6] T. Boellstorff, Queer Studies in the House of Anthropology, Annual Review of Anthropology 36 (2007) 17-35. DOI: https://doi.org/10.1146/annurev.anthro.36.081406. 094421 